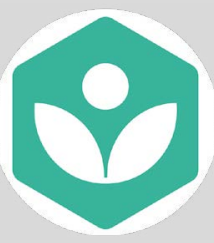

Khan Academy

\title{
Aprender QuímicaOnline
}

Khan Academy é uma organização sem fins lucrativos que tem como missão oferecer uma educação gratuita de elevada qualidade para qualquer pessoa, em qualquer lugar. No website podemos encontrar várias centenas de recursos e vídeos sobre diversas áreas do conhecimento, entre elas a química!

Destacamos um vídeo que nos conta a história da química atómica. Uma viagem no tempo que começa nas propostas da matéria dos filósofos grregos Leucipo e Demócrito e termina na teoria quântica de Heisenberg. Os vídeos estão narrados em português do Brasil e também são legendados. Boas aulas! Veja mais em pt.khanacademy.org/science/chemistry.

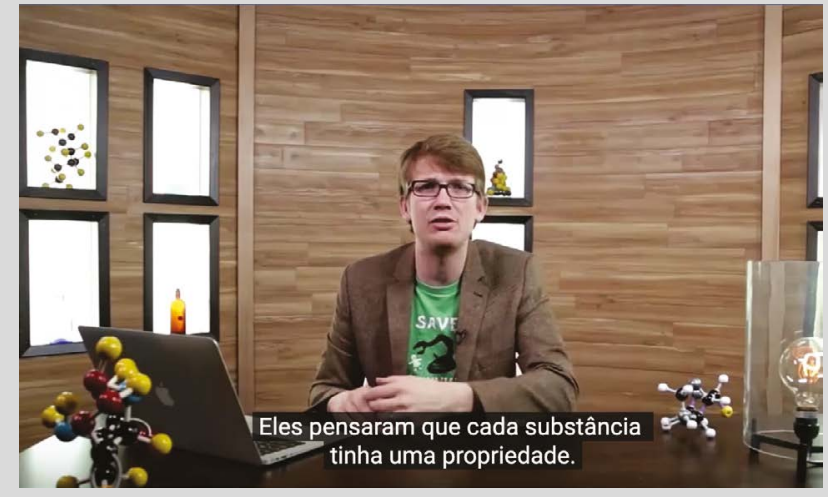

Vídeo da história da química atómica: bit.ly/khan-quimica-atomica

$>$

Vasco Bonifácio

vasco.bonifacio@tecnico.ulisboa.pt

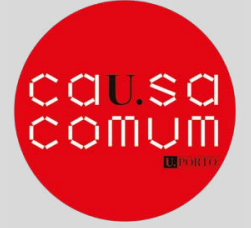

U. Porto

\section{Histórias de Desencantar}

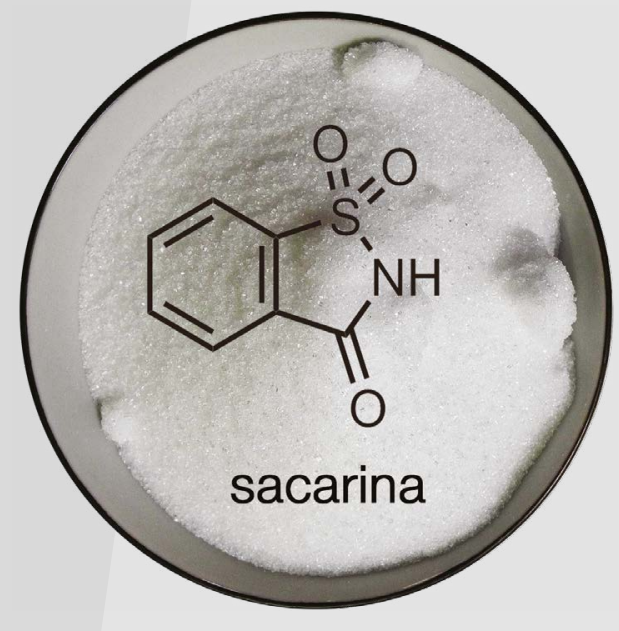

Podcast da história da sacarina: bit.ly/uporto-sacarina
O projeto Histórias de Desencantar tem como objetivo dar a conhecer descobertas científicas inovadoras que pela sua importância científica e social despertam a nossa curiosidade. São histórias que encantam e por vezes desencantam quando a descoberta leva a aplicações perversas. As histórias são contadas aos domingos, à meia-noite, pela voz de Susana Martinho e tendo por base textos escritos por Manuel João Monte do Departamento de Química e Bioquímica da Faculdade de Ciências da U. Porto e Centro de Investigação em Química da U. Porto.

Destacamos a história da sacarina. Este composto, 300 vezes mais doce que a sacarose, foi descoberto por acaso em 1878, e curiosamente depois de o provarmos ficamos com um ligeiro travo amargo na boca. Nesta história são personagens dois cientistas, Ira Remsen e Constantin Fahlberg, e o presidente americano Theodore Roosevelt Jr.

Veja mais em up.pt/casacomum/historias-de-desencantar-2.

$>$

Vasco Bonifácio

vasco.bonifacio@tecnico.ulisboa.pt 